\title{
PENGARUH LAMA WAKTU TUNGGU (HOLDING TIME) TERHADAP KADAR VITAMIN C DAN MUTU ORGANOLEPTIK PADA MILKSHAKE ANTI ANEMIA
}

\author{
THE EFFECT OF HOLDING TIME ON VITAMIN C LEVELS AND \\ ORGANOLEPTIC QUALITY OF ANTI-ANEMIA MILKSHAKE
}

\author{
Zanna Kusumawardhani, I Komang Suwita \\ Jurusan Gizi Poltekkes Kemenkes Malang \\ Email : ksuwita@gmail.com
}

\begin{abstract}
ABSTRAK
Penyebab utama anemia kurang besi adalah karena konsumsi zat besi yang tidak cukup dan absorbsi zat besi yang rendah dari pola makanan yang sebagian besar terdiri dari nasi, dan menu yang kurang beranekaragam. Secara ideal untuk mengatasi masalah anemia kurang besi adalah dengan cara meningkatkan absorbsi zat besi dengan meningkatkan kualitas menu makanan, yaitu dengan memasukan daging ikan, ayam, atau bahan-bahan makanan yang banyak mengandung vitamin C. Tujuan penelitian ini adalah mengetahui pengaruh lama waktu tunggu (Holding Time) pada formulasi terbaik dari pembuatan Milkshake Anti Anemi untuk remaja putri terhadap kadar Vitamin $\mathrm{C}$, dan mutu organoleptik. Hasil penelitian dari Nova Tantrin, 2015 telah didapatkan taraf perlakuan pembuatan Milkshake Anti Anemi terbaik yaitu pada perlakuan dengan komposisi jagung manis : kecambah kacang hijau : buah jambu biji merah (33\% : 16\% : 50\%). Dari hasil formulasi terbaik tersebut dilanjutkan dengan penelitian untuk mengetahui pengaruh lama waktu tunggu terhadap kadar vitamin $\mathrm{C}$, yaitu dengan lama waktu tunggu : 0 menit, 15 menit, 30 menit, 45 menit, 60 menit, menit dan 90 menit. Hasil penelitian menunjukan adanya penurunan kadar vitamin $\mathrm{C}$ pada waktu tunggu selama 90 menit yaitu sebesar 13\%, dan lama waktu tunggu (holding time) berpengaruh terhadap berubahnya aroma dan rasa dari Milkshake Anti Anemi tersebut.
\end{abstract}

Kata Kunci : Anemi defisit Fe, Lama Waktu Tunggu (Holding Time), Vitamin C, Mutu Organoleptik, Milkshake.

\begin{abstract}
ABSTRAC
The main causes of anemia are less iron is iron consumption is not enough and iron absorption are low because a diet consisting mostly of rice, and a less diverse of menu. The problem solving of anemia less iron is to increase iron absorption by increasing the quality of the diet, by consumption the fish meat, chicken, or foods that contain lots of vitamin C. The purpose of this study was to determine the effect of holding time at the best formulation of the making Milkshake Anti Anemi for girls on levels of vitamin C, and the organoleptic quality. Nova Tantrin research results (2015), has obtained the level of treatment
\end{abstract}


the making Anti Anemi best milkshakes that the treatment with the composition of sweet corn: mung bean sprouts: red guava fruit (33\%: 16\%: 50\%). The best formulation of the results continued with a study to determine the effect of holding time on levels of vitamin $\mathrm{C}$, which is the holding time of 0 minutes, 15 minutes, 30 minutes, 45 minutes, 60 minutes and 90 minutes. The results showed decrease the levels of vitamin $\mathrm{C}$ in a 90-minute holding time amounted to $13 \%$, and the holding time effect on the change in the aroma and flavor of the milkshake Anti Anemi..

\section{Keywords : Anemi deficiency Fe, Holding Time period, Vitamin C, Organoleptic Quality, Milkshake}

\section{PENDAHULUAN}

Penyebab utama anemia kurang besi tampaknya adalah karena konsumsi zat besi yang tidak cukup dan absorbsi zat besi yang rendah dari pola makanan yang sebagian besar terdiri dari nasi, dan menu yang kurang beranekaragam. Konsumsi zat besi dari makanan tersebut sering lebih rendah dari dua per tiga kecukupan konsumsi zat besi yang dianjurkan (RDA). Dan susunan menu makanan yang dikonsumsi tergolong pada tipe makanan yang rendah absorbsi zat besinya (Anwar, 1989).

Menurut Karyadi (1990) bahwa munculnya masalah gizi dapat terjadi sebenarnya karena disebabkan oleh beberpa hal, seperti perilaku yang keliru, dan perilaku ini mengarah pada terjadinya ketidakseimbangan antara konsumsi dan kecukupan gizinya. Dan pengetahuan terhadap gizi yang kurang juga akan memunculkan anggapan bahwa makanan yang baik dan menyehatkan adalah identik dengan makanan yang harganya mahal. Dikatakan pula bahwa dengan pengetahuan gizi yang baik maka akan dapat menghindarkan seseorang atau masyarakat dari paradigm/anggapan yang keliru.

Secara ideal untuk mengatasi masalah anemia kurang besi adalah dengan cara meningkatkan absorbsi zat besi dengan meningkatkan kualitas menu makanan, yaitu dengan memasukan daging, ikan, ayam, atau bahan-bahan makanan yang banyak mengandung vitamin $\mathrm{C}$. Tetapi cara pendekatan ini dirasakan mahal, dan sulit terjangkau oleh sebagian besar penduduk, maka dari itu diupayakan oleh pemerintah untuk pemanfaatan pangan fungsional yang bernilai gizi tinggi seperti seralia, kacang- 
kacangan, buah-buahan, dan sayursayuran (Cook, J.D dkk, 1976).

Jagung manis merupakan sumber karbohidrat, jagung manis juga merupakan sumber protein yang penting dalam menu masyarakat di Indonesia. Jagung manis kaya akan komponen pangan fungsional, termasuk serat pangan yang dibutuhkan tubuh, asam lemak esensial, isoflavon, mineral $(\mathrm{Ca}, \mathrm{Mg}$, $\mathrm{K}, \mathrm{Na}, \mathrm{P}, \mathrm{Ca}$, dan $\mathrm{Fe}$ ), antosianin, beta karoten (Provitamin A), komposisi asan amino esensial, dan lainnya. Nilai gizi jagung manis/100 gr bahan adalah Energi 96,0 kal; Protein 3,5 gr; Lemak 1 gr; Karbohidrat 22,8 gr; Vitamin C 12,0 mg; dan Fe 0,7 mg (Suarni, 2011).

Pangan sumber protein nabati maliputi kedele, kacang-kacangan dan hasil olahannya. Kacang hijau merupakan sumber protein nabati, sumber vitamin $\left(A, B_{1}, C\right.$ dan $\left.E\right)$ serta beberapa zat lain yang sangat bermanfaat bagi tubuh manusia, seperti amilum, besi, belerang, kalsium, lemak, mangan, magnesium dan niasin. Kacang hijau mengandung $20-25 \%$ protein dan protein kacang hijau mempunyai asam amino essensial yang dapat meningkatkan penyerapan besi dalam usus halus, antara lain lysisn 65.5 mg/g. Namun kenyataannya penyediaan protein sering defisit pada menu makanan sehari-hari (Hardinsyah dan Dodik B., 1994). Protein mempunyai peranan penting dalam transportasi zat besi dalam tubuh. Kurangnya asupan protein akan mengakibatkan transportasi zat besi terhambat sehingga akan terjadi defisiensi zat besi disamping itu makanan yang tinggi protein, terutama yang berasal dari ikan, daging, dan unggas juga mengandung banyak zat besi (Husaini’ 1989).

Buah jambu biji sangat bergizi karena mengandung asam askorbat (50-3000 $\mathrm{mg} / 100 \mathrm{~g}$ berat segar, tiga sampai enam kali lebih tinggi dari pada jeruk (Thaipong, dkk 2006). Lama proses penyimpnan juga berpengaruh terhadap kadar vitamin $\mathrm{C}$, karena sifat yang paling utama dari vitamin $\mathrm{C}$ adalah kemampuan mereduksinya yang kuat dan mudah teroksidasi (Koswara, Nuri Andarwulan Sutrisno, 1992). Salah satu fungsi vitamin $\mathrm{C}$ yang sangat penting adalah meningkatkan kemampuan absorbsi zat besi nonheme. Dalam absorbsi dan 
metabolisme besi, vitamin $\mathrm{C}$ mereduksi feri menjadi fero dalam usus halus sehingga mudah diabsorbsi. Absorbsi besi dalam bentuk nonhem meningkat empat kali lipat bila ada vitamin C. Vitamin C berperan dalam memindahkan besi dari transferin di dalam plasma ke feritin hati.

Ketiga jenis bahan makanan tersebut di atas (jagung, kacang hijau dan jambu biji) memiliki kandungan jenis zat gizi yang berbeda, dan dapat saling melengkapi dalam rangka mencegah terjadinya anemia. Maka dari itu, ketiga bahan makanan tersebut diformulasi menjadi milkshake sebagai snack untuk penderita anemia. Minuman tambahan atau snack adalah istilah bagi makanan yang bukan merupakan menu utama (makan pagi, makan siang, atau makan malam). Makanan yang dianggap makanan ringan adalah sesuatu yang dimaksudkan untuk menghilangkan rasa lapar seseorang sementara waktu, memberi sedikit suplai energi ke tubuh, atau sesuatu yang dimakan untuk dinikmati rasanya.

Penderita anemi membutuhkan diit Tinggi Energi dan
Tinggi Protein, salah satunya didapatkan dari konsumsi snack sehari-hari. Milkshake Anti Anemi merupakan snack yang padat gizi dibandingkan dengan jus buah, karena di dalam Milkshake Anti Anemi terdapat sumber protein, vitamin, dan mineral. Dimana ketiga zat gizi tersebut dibutuhkan bagi penderita anemi (Muhilal, 1993).

Pada penelitian Pembuatan Milkshake Anti Anemi dengan komposisi bahan utama yaitu jagung manis (Zea mays), kacang hijau (Vigna radiata), dan jambu biji merah (Psidium guajava L.) telah didapatkan perlakuan terbaik yaitu $\mathrm{P}_{3}$ dengan perbandingan $33: 16: 50$

Dalam persiapan bahan makanan yang akan diberikan kepada pasien, milkshake harus melewati proses pengolahan sampai dengan pendistribusian.

Dalam pendistribusian makanan dibedakan menjadi dua metode yaitu sentralisasi dan desentralisasi (Bakri Bachyar dkk, 2013), tenggang waktu dari pengolahan sampai penyajian makanan dapat menurunkan nilai gizi. Pada jambu merah dengan waktu tunggu selama 60 menit menyebabkan penurunan vitamin $\mathrm{C}$ 
sebanyak 44\% (Adamsari, 2011). pengaruh holding time terhadap kadar Waktu tunggu snack cair di rumah sakit sangat bervariasi, mulai dari vitamin $\mathrm{C}$ dan mutu organoleptik Milkshake Anti Anemi.

sekitar 60 menit sampai lebih dari 90 menit sejak snack itu dibuat.

Dalam pembuatan Milkshake Anti Anemi, vitamin C pada buah jambu biji (Psidium guajava L.) berperan dalam peningkatan absorpsi zat besi non heme dari jagung manis (Zea mays) dan kacang hijau (Vigna radiata) sampai empat kali lipat (Cook, J.D dan Monsen, E.R, 1976).

Asam askorbat atau vitamin $\mathrm{C}$ adalah vitamin yang mudah larut dalam air. Dalam keadaan kering vitamin $\mathrm{C}$ cukup stabil, tetapi dalam keadaan larut vitamin $\mathrm{C}$ mudah rusak karena bersentuhan dengan udara (oksidasi) terutama bila terkena panas. Oksidasi dipercepat dengan kehadiran tembaga dan besi (Almatsier, 2006).

Menindaklanjuti penelitian dari Adamsari, D.F. (2011) tentang Pengaruh Oksidasi Pada Waktu Tunggu (Holding Time) Terhadap Kadar Vitamin C, pH, dan Mutu Organoleptik Jus Jambu Biji (Psidium Guajava, L) Sebagai Sumber Antioksidan, maka peneilitian ini dirancang untuk mengetauhui

\section{BAHAN DAN METODE}

Pelaksanaan Penelitian

Penelitian dilaksanakan pada bulan Februari 2015 di Laboratorium Ilmu Bahan Makanan dan Laboratorium Kimia Jurusan Gizi Poltekkes Kemenkes Malang.

\section{Alat dan Bahan}

1. Alat

a. Pengolahan Milkshake

Alat untuk pengolahan milkshake anti anemi adalah baskom, sendok, blender, kain saring, beaker glass, panci, spatula, dan gelas ukur.

b. Waktu Tunggu (Holding Time)

Peralatan untuk menghitung waktu tunggu (holding time) milkshake anti anemi adalah stopwatch, dan alat tulis.

c. Uji Kadar Vitamin C

Peralatan untuk uji kadar vitamin $\mathrm{C}$ adalah erlenmayer, pipet ukur, pipet volume dan alat titrasi. 
d. Analisis Mutu Organoleptik

Peralatan untuk analisis mutu organoleptik adalah Kuisioner, alat tulis (bolpoint), gelas kecil, sendok, gelas, nampan kecil.

2. Bahan

Jagung manis, kecambah kacang hijau, jambu merah, susu kental manis, vanila, gula pasir, kayu manis.

Bahan yang digunakan untuk menguji kadar vitamin $\mathrm{C}$ adalah sample bahan (milkshake anti anemi), aquadest, amilum $1 \%$, larutan $0,1 \mathrm{~N}$ yodium.

\section{METODE PENELITIAN}

Penelitian ini menggunakan jenis penelitian eksperimen laboratorium dengan desain penelitian Rancangan Acak Lengkap (RAL) menggunakan 7 (tujuh) taraf perlakuan lama waktu tunggu (holding time), yaitu : 0 menit, 15 menit, 30 menit, 45 menit, 60 menit, 75 menit dan 90 menit.
Masing-masing taraf perlakuan dilakukan 3 kali pengulangan. Pengaruh holding time terhadap kadar vitamin C dianalisis secara statistik, yaitu dengan análisis One Way Anova pada tingkat kepeercayaan 95\% digunakan untuk variabel terikat yang berskala interval atau rasio yaitu kadar vitamin C. Metode analisis Iodo-Iodimetri ditetapkan menggunakan banyaknya $I_{2}$ yang bereaksi dengan asam askorbat adalah ekuivalent dengan jumlah vitamin $\mathrm{C}$. Pengaruh holding time terhadap mutu organoleptik pada tingkat kepercayaan $95 \%$ yaitu digunakan análisis statistik Kruskal Wallis. 


\section{HASIL DAN PEMBAHASAN}

A. Kadar Vitamin C

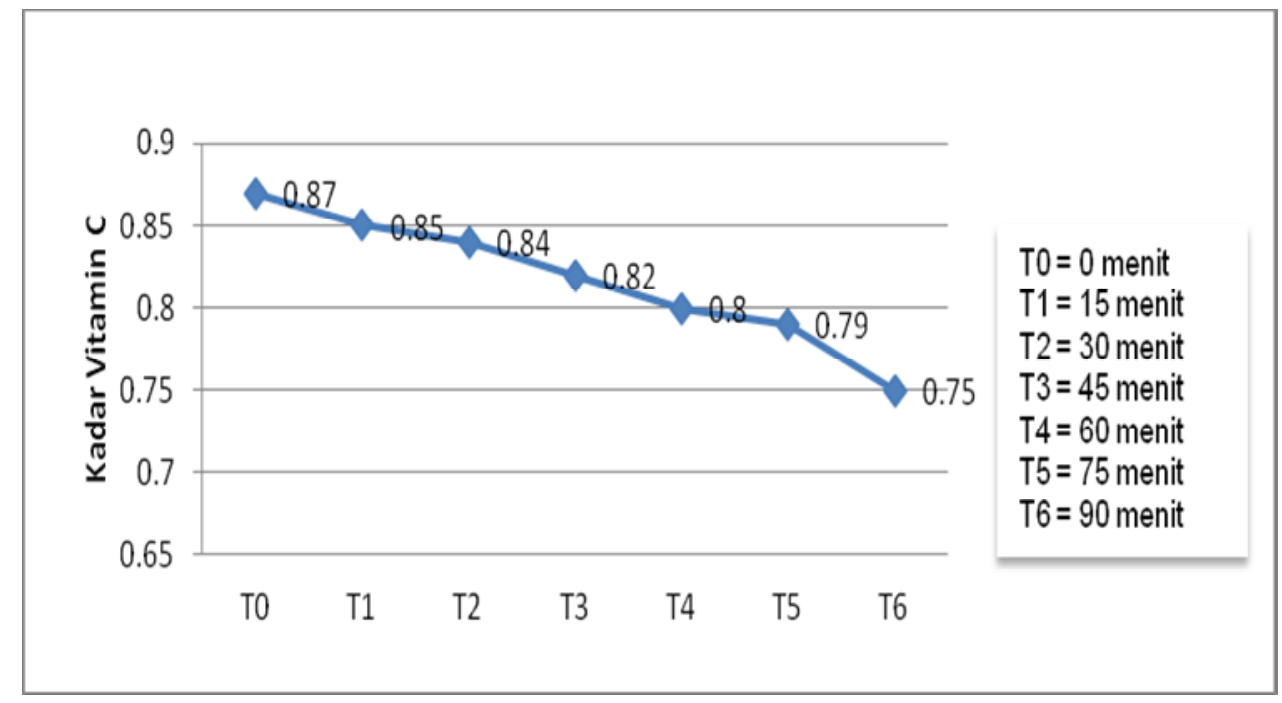

Gambar. Penurunan Kadar Vitamin C berdasar Lama Waktu

\section{Tunggu.}

Waktu tunggu (holding time) milkshake sebelum dikonsumsi memiliki dampak yang sangat besar terhadap penurunan kandungan vitamin C. Penurunan kadar vitamin $\mathrm{C}$ milkshake anti anemi menunjukkan kecepatan penurunan yang cukup tinggi. Selama 30 menit pertama penurunan kadar vitamin $\mathrm{C}$ milkshake anti anemi mencapai 4\%, dan meningkat menjadi $8 \%$ dan $13 \%$ masing-masing pada menit ke-60 dan ke-90. Jadi, jika milkshake tersebut disajikan kepada konsumen dalam waktu 90 menit setelah pembuatannya, kandungan vitamin C milkshake anti anemi sebenarnya telah menurun sebesar $13 \%$ dari yang dibutuhkan untuk menanggulangi anemi. Idealnya konsumsi minuman yang mengandung vitamin $\mathrm{C}$ tinggi dilakukan segera setelah dibuat, atau setidaknya dihabiskan dalam waktu satu jam. (Wirakusumah, 2013).

Penurunan kadar Vitamin C terjadi secara signifikan, dengan interval penurunan $0.1 \%$ sampai 0.6\% per 15 menit. Hal ini terjadi karena Vitamin $\mathrm{C}$ merupakan vitamin yang mudah teroksidasi. Vitamin $\mathrm{C}$ juga akan hilang sejak dipanen hingga sampai di meja makan. Kedaan yang menyebabkan 
kehilangan vitamin $\mathrm{C}$ adalah : lama

disimpan dalam suhu panas, membiarkan lama terbuka pada udara (oksidasi), pencucian, pemotongan, prendaman dalam air, memasak dengan suhu tinggi untuk waktu lama, memasak dalam panci besi atau tembaga, membiarkan lama sesudah dimasak pada suhu kamar atau suhu panas sebelum dimakan (Almatsier, 2006).

Berdasarkan hasil uji statistik One Way Anova pada tingkat kepercayaan menunjukkan bahwa lama waktu tunggu (holding time) memberikan pengaruh yang signifikan $(p=0,000)$ terhadap kadar Vitamin C pada milkshake anti anemi (Lampiran 4). Hasil yang signifikan dilanjutkan dengan uji lanjutan yaitu dengan analisis Last Significance Difference (LSD) menunjukkan bahwa milkshake dengan lama waktu tunggu (holding time) 0 menit memiliki perbedaan kadar Vitamin C yang signifikan dengan milkshake anti anemi dengan lama waktu tunggu 30, 45, 60, 75, dan 90 menit. Semakin lama waktu tunggu (holding time) maka penurunan kadar Vitamin C semakin tinggi, penurunan kadar Vitamin $\mathrm{C}$ dapat dipengaruhi terhadap lamanya milkshake terpapar dengan udara, karena salah satu sifat Vitamin C yaitu mudah teroksidasi (Thurnham dkk, 2000).

\section{B. Mutu Organoleptik}

\section{Warna}

Tingkat penerimaan panelis terhadap milkshake anti anemi berdasarkan hasil uji organoleptik, dari 20 panelis didapatkan nilai ratarata warna milkshake anti anemi berkisar antara 2.9 sampai 3.1 . Perolehan tertinggi sebesar 3.1 dengan kriteria suka (mdous: 3) yang didominasi oleh warna jambu biji yaitu berwarna merah muda. Karena karakteristik warna buah jambu biji yang segar dan matang yaitu merah muda. Hasil analisis statistik Kruskal Wallis pada tingkat kepercayaan $95 \%$ menunjukkan bahwa lama waktu tunggu (holding time) tidak memberikan pengaruh yang signifikan $(p=0.024)$ terhadap perubahan warna pada milkshake anti anemi. Hal ini berarti warna yang dihasilkan dari milkshake anti anemi tidak memperlihatkan perbedaan yang berarti dari perlakuan pada 0 menit sampai 90 menit. Warna merah muda yang 
dihasilkan didominasi dari buah jambu segar, sedangkan penambahan jagung manis dan kacang hijau tidak memberi banyak pengaruh untuk warna milkshake anti anemi.

\section{Aroma}

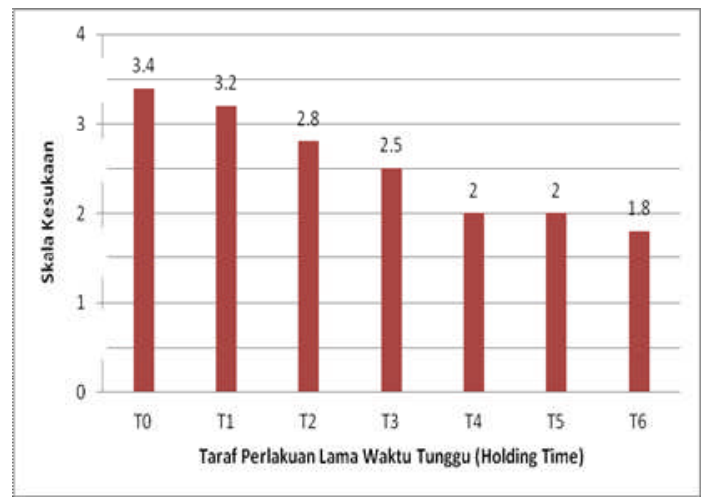

Gambar. Tingkat Kesukaan Panelis terhadap Aroma Milkshake Anti Anemi.

Berdasarkan hasil uji organoleptik dari 20 panelis nilai rata-rata aroma dari milkshake anti anemi adalah 2.7 sampai 3.7. Perolehan tertinggi sebesar 3.7 dengan kriteria suka beraroma jambu yang khas pada perlakuan lama waktu tunggu (holding time) 0 menit. Sedangkan nilai terendah 2.7 dengan kriteria tidak suka beraroma jagung manis Hasil analisis statistic Kruskal Wallis pada tingkat kepercayaan $95 \%$ menunjukkan bahwa lama waktu tunggu (holding time) milkshake anti anemi memberikan pengaruh yang signifikan $(\mathrm{p}=0,000)$ terhadap aroma dari milkshake.

Hasil uji lanjut Mann-Whitney menunjukkan bahwa pasangan taraf perlakuan yang memberikan pengaruh signifikan adalah antara 0 menit - 30 menit; 0 menit - 45 menit; 0 menit - 60 menit; 0 menit 75 menit; 0 menit - 90 menit; 15 menit - 45 menit; 15 menit 75 menit; 15 menit - 90 menit; 30 menit - 75 menit; 30 menit - 90 menit; 45 menit - 90 menit (dengan perlakuan : $\mathrm{T} 0=0$ menit; $\mathrm{T} 1=15$ menit; $\mathrm{T} 2=30$ menit; $\mathrm{T} 3=45$ menit; $\mathrm{T} 4=60$ menit; $\mathrm{T} 5=75$ menit; $\mathrm{T} 6=90$ menit).

Pada perlakuan di 0 menit (T0) nilai tertinggi diperoleh karena jambu biji memiliki bau yang khas yaitu berasal dari kandungan senyawa eugenol yang dimiliki jambu biji (Redaksi Agromedia, 2009). Pada menit ke 0 milkshake anti anemi disajikan dalam keadaan masih segar, sehingga bau khas jambu biji masih terasa kuat. Seiring bertambahnya lama waktu tunggu membuat penilaian panelis menurun terhadap aroma dari 
milkshake anti anemi ini, hal ini dikarenakan bau yang tercium kuat adalah bau jagung manis yang agak sedikit langu. Etanol yang teroksidasi dalam pati jagung membentuk asam organik yang dapat menimbulkan rasa dan aroma yang khas yang tercium kuat.

\section{Rasa}

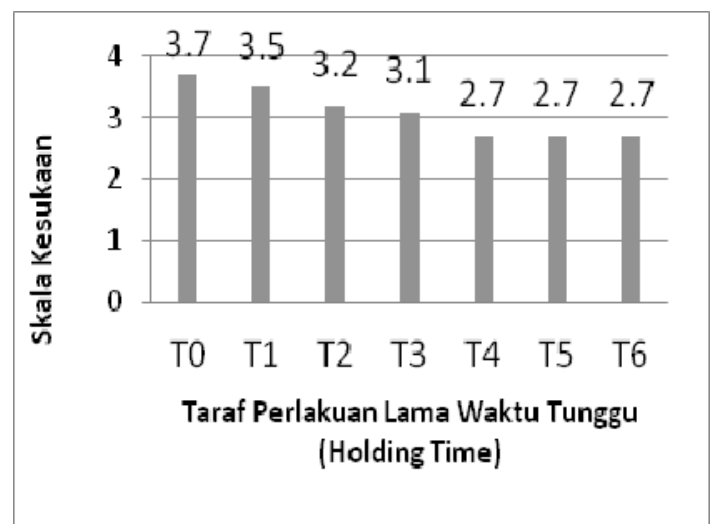

Gambar. Tingkat Kesukaan Panelis terhadap Rasa dari Milkshake Anti Anemi.

Berdasarkan hasil uji organoleptik dari 20 panelis nilai rata-rata rasa dari milkshake anti anemi adalah 1.8 sampai 3.4. Perolehan tertinggi sebesar 3.4 dengan kriteria suka rasa manis dari jambu biji pada perlakuan lama waktu tunggu (holding time) 0 menit. Sedangkan nilai terendah 1.8 dengan kriteria tidak suka dengan rasa dari kecambah kacang hijau pada perlakuan lama waktu tunggu (holding time) 45-90 menit. Nilai rata-rata tingkat kesukaan panelis terhadap rasa dari milkshake anti anemi tersaji pada.

Hasil analisis statistik Kruskal Wallis pada tingkat kepercayaan $95 \%$ menunjukkan bahwa lama waktu tunggu (holding time) milkshake anti anemi memberikan pengaruh yang signifikan $(\mathrm{p}=0,000)$ terhadap rasa dari milkshake. Hasil uji lanjutan Mann-Whitney menunjukkan bahwa pasangan taraf perlakuan yang memberikan pengaruh signifikan yaitu antara 0 menit - 30 menit; 0 menit - 45 menit; 0 menit - 60 menit; 0 menit - 75 menit; 0 menit 90 menit; 15 menit - 30 menit; 15 menit 45 menit; 15 menit - 60; 15 menit - 75 menit; 15 menit - 90 menit; 30 menit - 45 menit; 30 menit - 60 menit; 30 menit - 75 menit; 30 menit - 90 menit; 45 menit - 90 menit (dengan perlakuan $: \mathrm{T}_{0}=0$ menit; $\mathrm{T}_{1}=15$ menit; $\mathrm{T}_{2}=$ 30 menit; $\mathrm{T}_{3}=45$ menit; $\mathrm{T}_{4}=60$ menit; $\mathrm{T}_{5}=75$ menit; $\mathrm{T}_{6}=90$ menit).

Milkshake anti anemi memiliki rasa yang manis dan after taste langu. Rasa manis 
dikarenakan adanya penambahan gula pasir dan sedikit susu kental manis dalam pembuatan milkshake anti anemi ini. Penambahan gula pasir dan sedikit susu kental manis berfungsi untuk meningkatkan sifat dan mutu sensorik sehingga meningkatkan daya terima produk. Pada perlakuan di 0 menit $\left(\mathrm{T}_{0}\right)$ nilai tertinggi diperoleh karena jambu biji memiliki bau yang khas yaitu berasal dari kandungan senyawa eugenol yang dimiliki jambu biji (Redaksi Agromedia, 2009). Sedangkan pada perlakuan lama waktu tunggu (holding time) 45-90 menit $\left(\mathrm{T}_{4}-\mathrm{T}_{6}\right)$ rasa yang timbul adalah rasa langu yang berasal dari kecambah kacang hijau. Sebagaimana dijelaskan Koswara, 2010 bahwa kacang-kacangan mengandung senyawa off-flavour (menimbulkan baud an rasa yang tidak dikehendaki yaitu penyebab langu (beany flavor)). Hal ini mengakibatkan penilaian panelis menurun seiring dengan bertambahnya lama waktu tunggu (holding time) pada milkshake anti anemi.

\section{KESIMPULAN DAN SARAN}

Penurunan kadar vitamin $\mathrm{C}$ milkshake anti anemi menunjukkan kecepatan penurunan yang cukup tinggi. Selama 30 menit pertama penurunan kadar vitamin $\mathrm{C}$ milkshake anti anemi mencapai $4 \%$, dan meningkat menjadi $8 \%$ dan $13 \%$ masing-masing pada menit ke-60 dan ke-90.

Tingkat penerimaan panelis terhadap milkshake anti anemi berdasarkan hasil uji organoleptik, dari 20 panelis didapatkan nilai ratarata warna milkshake anti anemi berkisar antara 2.9 sampai 3.1 . Perolehan tertinggi sebesar 3.1 dengan kriteria suka (mdous: 3) yang didominasi oleh warna jambu biji yaitu berwarna merah muda. Karena karakteristik warna buah jambu biji yang segar dan matang yaitu merah muda.

Berdasarkan hasil uji organoleptik dari 20 panelis nilai rata-rata aroma dari milkshake anti anemi adalah 2.7 sampai 3.7. Perolehan tertinggi sebesar 3.7 dengan kriteria suka beraroma jambu yang khas pada perlakuan lama waktu tunggu (holding time) 0 menit. Sedangkan nilai terendah 2.7 
dengan kriteria tidak suka beraroma jagung manis

Berdasarkan hasil uji organoleptik dari 20 panelis nilai rata-rata rasa dari milkshake anti anemi adalah 1.8 sampai 3.4. Perolehan tertinggi sebesar 3.4 dengan kriteria suka rasa manis dari jambu biji pada perlakuan lama waktu tunggu (holding time) 0 menit.

\section{DAFTAR PUSTAKA}

Adamsari, D.F. 2011. Pengaruh Oksidasi Pada Waktu Tunggu (Holding Time) Terhadap Kadar Vitamin $C$, pH, dan Mutu Organoleptik Jus Jambu Biji (Psidium guajava, L.) sebagai Sumber Antioksidan. Skripsi (unpublished), Universitas Brawijaya.

Almatsier, Sunita. 2006. Prinsip Dasar Ilmu Gizi. Jakarta : Gramedia Pustaka Utama Anwar, Mahidin dkk. 1989. Study Nutritional Anemia an Assessment of Information Compilation for Supporting and Formulating National Policy and Program.
Laporan Akhir Penelitian : Depkes RI.

Bakri, Bachyar dkk. 2013. Buku Ajar Manajemen System Penyelenggaraan Makanan (Food Service Management) Buku I : Poltekkes Malang.

Cook, J.D dan Monsen, E.R. 1976. Food Iron Absorption ini Human Subjects, III. Comparison of the Effects of Animal Protein on Nonheme Iron Absorption. Am.J.Clin.Nutr. 29: 859866.

Cook, J.D dan Monsen, E.R. 1976. Vitamin C, The Common Cold, and Iron Absorption in Man. Am.J. Clin. Nutr. 30: $235-240$.

Hardinsyah, Briawan D. 1994. Penilaian dan Perencanaan Konsumsi Pangan. Diktat Jurusan Gizi Masyarakat dan Sumberdaya Keluarga. Fakultas Pertanian. Bogor: IPB.

Karyadi \& Muhilal. 1990. Kecukupan Gizi yang Dianjurkan.Jakarta:

Gramedia 
Koswara, 2010. Kacang-kacangan sumber serat kaya gizi. http://www.ebokpangan.com

Husaini, Mahdin Anwar dkk. 1989. Study Nutritional Anemia an Assessment of Information Compilation for Supporting and Formulating National Policy and Program. WHO

Muhilal, dkk. 1993. Angka Kecukupan Gizi yang Dianjurkan WKPG $V$. Jakarta : LIPI.

Redaksi AgroMedia. 2009. Buku Pintar Budi Daya Tanaman Buah Unggul Indonesia. Agromedia Pustaka, Jakarta. Suarni dkk. 2011. Jagung Sebagai Sumber Pangan Fungsional. Jurnal Iptek Tanaman Pangan Vol. 6 No. 1 :

Bandung.

Koswara, Nuri Andarwulan Sutrisno, 1992. Kimia Vitamin. Edisi pertama, Jakarta.Rajawali Pers

Thaipong K., Boonprakob U., Crosby K., CisnerosZevallos L., Byrne H.D., 2006. C omparison of
ABTS, DPPH, FRAP and ORAC assays for estimating antioxidant activity from guava fruit extracts. J. Food Comp. Anal. 19, 669-675.

Thurnham D.I., Bender D.A., Scott J., dan Halsted C.H. 2000. Water Soluble Vitamins, dalam Human Nutrition and Dietatics (Garrow J.S., James W.P. T., and Ralph A., eds) hal 249-257, Harcourt Publisher Limited, United Kingdom.

Wirakusumah, Emma S. 2013. Jus sehat Buah \& Sayuran. Jakarta : Penebar Swadaya. 